\title{
ANALISIS TERHADAP PEMIKIRAN HAMKA DAN MUHAMMAD IQBAL TENTANG TUJUAN PENDIDIKAN
}

\author{
Lailatu Zahroh ${ }^{1}$ \\ e-mail : lailatuzahro@gmail.com
}

STAI TARUNA SURABAYA

\begin{abstract}
Abstrak: Tujuan merupakan standar usaha yang dapat ditentukan, serta mengarahkan usaha yang akan dilalui dan merupakan titik pangkal untuk mencapai tujuan-tujuan lain. Disamping itu, tujuan dapat membatasi ruang gerak usaha, agar kegiatan dapat terfokus pada apa yang dicita-citakan, dan yang terpenting lagi adalah dapat memberI penilaian atau evaluasi pada usahausaha pendidikan. Pendidikan seharusnya berorientasi pada tujuan yang ingin dicapai, bukan semata-mata berorientasi pada sederetan materi, karena itulah tujuan pendidikan harus dirumuskan terlebih dahulu sebelum merumuskan komponen pendidikan yang lain Bagaimanakah tujuan pendidikan menurut Muhammad Iqbal dan HAMKA? Apa persamaan dan perbedaan antara keduanya?
\end{abstract}

Kata kunci: pemikiran Hamka, pemikiran Iqbal, tujuan pendidikan

\section{A. Pendahuluan}

HAMKA dan Muhammad Iqbal, keduanya tidak secara tegas dikelompokkan oleh para ahli sebagai seorang ahli pendidikan, namun sesungguhnya keduanya banyak memaparkan konsep dan teori pendidikan yang relative original dan patut dikembangkan. Muhammad Iqbal dan HAMKA tidak hanya dapat digolongkan sebagai pemikir masalah pendidikan, tetapi juga sebagai praktisi pendidikan.

Profesi HAMKA sebagai katib atau jurnalis secara langsung menempatkan sosok HAMKA sebagai pendidik, apalagi diantara karyanya tidak sedikit yang memuat pikiran-pikirannya dalam bidang pendidikan yang dilandasi oleh pemikirannya tentang manusia sebagai obyek sasaran pendidikan. Demikian juga dalam kapasitasnya sebagai praktisi pendidikan dijalaninya dalam kurun waktu yang sangat lama, yaitu diawali dengan aktivitasnya memimpin lembaga pendidikan bernama Tabligh School ${ }^{2}$ kemudian mendirikan dan memimpin lembaga pendidikan yang bernama Kulliyatul Muballighien di Padangpanjang ${ }^{3}$. Aktivitas ini-sebagai pemikir dan praktisi pendidikan- dilakukan oleh HAMKA secara konsisten sampai

\footnotetext{
${ }^{1}$ Dosen Tetap STAI Taruna Surabaya

2 Tabligh Scool merupakan lembaga pendidikan yang mencetak para kader dakwah Islamiyah. Tabligh School ini didirikan pada tahun 1929 dan dipimpin oleh HAMKA. Namun dketika HAMKA pindah ke Makassar (1931-1934) Tabligh School dihentikan, sebab pada saat itu di Padangpanjang reltif tidak ada tokoh yang dianggap representative menggnatikannya. Lihat Agus Hakim, Kulliyatul Mubalighien Muhammadiyah dan Buya HAMKA, 1978, Kenang-kenangan 70 Tahun Buya HAMKA, Jakarta, Yayasan Nurul Islam, halam 46-64
} 
akhir hayatnya, dengan menggunakan berbagai media pendidikan, seperti halaqah-halaqah, lembaga dakwah dan media massa.

Muhammad Iqbal melakukan kritik terhadap system pendidikan Barat dan system pendidikan Islam. Menurut Iqbal, perlu dilakukan rekonstruksi terhadap pendidikan Islam sehingga didalamnya mampu mensintesakan hal-tal terbaik dari system pendidikan Barat dan juga dari system pendidikan Islam. Dalam rumusan Iqbal, sintesa dari system pendidikan Barat dan system pendidikan Timur ini disebutnya sebagai rekonstruksi pemikiran Islam.

Bertolak dari pernyataan-pernyataan diatas, peneliti tertarik mengadakan penelitian tentang rekonstruksi pendidikan dengan membandingkan antara pendidikan dalam pemikiran Muhammad Iqbal dan HAMKA.

\section{B. Pemikiran HAMKA tentang Tujuan Pendidikan}

Dalam adagium ushuliyah dinyatakan bahwa "al umur bi maqashidiha", bahwa setiap tindakan dan aktivitas harus berorientasi pada tujuan atau rencana yang telah ditetapkan. Adagium ini menunjukkan bahwa Pendidikan seharusnya berorientasi pada tujuan yang ingin dicapai, bukan semata-mata berorientasi pada sederetan materi.

Perumusan tujuan pendidikan harus berorientasi pada hakikat pendidikan yang meliputi beberapa aspek, yaitu: (1) Tujuan dan tugas hidup manusia. Manusia hidup bukan karena kebetulan dan sia-sia. Ia diciptakan dengan membawa tujuan dan tugas hidup tertentu (QS. Ali Imron: 191). Tujuan diciptakan manusia hanya untuk mengabdi kepada Allah saw. Indikasi tugasnya berupa Ibadah (sebagai 'abd Allah) dan tugas sebagai wakil-Nya di muka bumi (khalifah Allah) seperti dalam QS Al An'am: 162), (2) memperhatikan sifat-sifat dasar (nature) manusia, yaitu konsep tentang manusia sebagai makhluk unik yang mempunyai beberapa potensi bawaan, seperti fitrah, bakan, minat, sifat dan karakter, yang berkecenderungan pada al-hanief (rindu akan kebenaran dari Tuhan) berupa agama Islam (QS al Kahfi: 29) sebaas kemampuan, kapasitas dan ukuran yang $\operatorname{ada}^{4}$. (3) Tuntutan masyarakat. Tuntutan ini baik berupa pelestarian nilai-nilai budaya yang telah melembaga dalam kehidupan suatu masyarakat, maupun pemenuhan terhadap tuntutan kebutuhan hidupnya dalam mengantisipasi perkembangan dunia modern. (4) Dimensi-dimensi kehidupan ideal Islam. Dimensi ini mengandung nilai yang dapat meningkatkan kesejahteraan hidup manusia di dunia untuk mengelola dan memanfaatkan dunia sebagai bekal kehidupan di akhirat, serta mengandung nilai yang mendorong manusia berusaha keras

\footnotetext{
${ }^{4}$ Hasan Langgulung, 1989, Manusia dan Pendidikan, Suatu Analisis Psikologi dan Pendidikan, Jakarta Pustaka al-Husna, halaman 34
} 
untuk meraih kehidupan di akhirat yang lebih baik ${ }^{5}$ HAMKA juga berpendapat bahwa setiap upaya manusia dalam melaksanakan berbagai aspek kehidupan, termasuk aspek pendidikan, harus ada ghoyah (tujuan) dan wasilah (metode). Ghoyah adalah pernyataan tujuan yang akan diwujudkan, sedangkan wasilah adalah metode atau cara yang akan dilakukan untuk mewujudkan tujuan tersebut.

Pendidikan merupakan aktivitas yang sistematis dan terencana dalam rangka memenuhi tujuan hidup manusia, yaitu:

\section{Khalifah Allah fi al-Ardl ${ }^{6}$}

Untuk lebih menegaskan fungsi kekhalifahan manusia di alam ini, dapat dilihat dari QS.al-An'am, 6: 165

"Dan Dialah yang menjadikan kamu penguasa-penguasa di bumi dan Dia meninggikan sebagian kamu atas sebagian (yang lain) beberapa derajat"

Juga dalam QS. Fathir, 35: 39

"Dialah yang menjadikan kamu khalifah-khalifah dimuka bumi. Barangsiapa yang kafir, maka (akibat) kekafirannya menimpa dirinya sendiri"

Juga dalam QS.al-A'raf, 7: 69

"Dan ingatlah oleh kamu sekalian diwaktu Allah menjadikan kamu sebagai pengganti (yang berkuasa) sesudah lenyapnya Nuh, dan Tuhan telah melebihkan kekuatan tubuh dan perawakanmu (dari pada kaum Nuh itu)

Ayat-ayat tersebut disamping menjelaskan kedudukan manusia dialam raya ini sebagai khalifah dalam arti yang luas juga memberi isyarat tentang perlunya sikap moral atau etik yang harus ditegakkan dalam melaksanakan fungsi kekhalifahannya itu. Sebagai khalifah Allah manusia memiliki tugas sebagai wakil Allah di muka bumi yang diberi mandat untuk mewujudkan kemakmuran dan kesejahteraan hidup, dengan cara mengolah dan mendayagunakan apa yang ada di bumi untuk kepentingan hidupnya. Dengan demikian, tugas kekhalifahan ini pada dasarnya merupakan tugas kebudayaan yang berciri kreatif agar selalu

\footnotetext{
${ }^{5}$ Abdul Mujib, 2006, Ilmu Pendidikan Islam, Jakarta, Kencana Prenada Media, halaman

${ }^{6}$ HAMKA, 1997, Lembaga Hidup, Jakarta, Pustaka Panjimas, halaman 190
} 
dapat menciptakan sesuatu yang baru sesuai dengan kebutuhan pertumbuhan dan perkembangan masyarakat ${ }^{7}$

\section{Abd al-Allah ${ }^{8}$}

Kedudukan lainnya dari manusia dialam ini yang sering diangkat oleh para pakar ialah sebagai hamba yang harus beribadah kepada Allah. Hal ini biasanya didasarkan pada petunjuk ayat yang artinya: "Tidaklah Aku menciptkan jin dan manusia kecuali agar mereka menyembah (ibadah) kepada-Ku" (QS.al-Dzariyat, 51: 56) Pengertian ibadah dalam ayat ini menurut Hasan Langgulung adalah merupakan pengembangan fitrah itu setinggi-tingginya, yang oleh aliran kemanusiaan disebut perwujudan diri (self actualization) ${ }^{9}$. Penjelasan ini erat kaitannya dengan pelaksanaan fungsi kekhalifahan sebagaimana telah diuraikan diatas. Dengan ungkapan lain bahwa pelaksanaan ibadah ini pada hakikatnya adalah dalam rangka melaksanakan fungsi kekhalifahan sebagaimana telah disebutkan diatas.

Sementara itu Musa Asy'ari mengatakan bahwa esensi 'abd adalah ketaatan, ketundukan, dan kepatuhan yang semuanya itu hanya layak diberikan pada Tuhan. Ketundukan dan ketaatan pada kodrat alamiah yang senantiasa berlaku baginya. Ia terikat oleh hokum-hukum Tuhan yang menjadi kodrat pada setiap ciptaanNya, manusia menjadi bagian dari ciptaanNya, ia bergantung dengan sesamanya, hidup dan mati menjadi bagiannya yang pasti. Akan tetapi manusia tidak terikat sepenuhnya oleh hokum-hukum alamiah saja, karena sebagai makhluk yang dilebihkan daripada alam ciptaan Tuhan lainnya, manusia diberikan kemampuan akalnya, sehingga mampu mengolah potensi alam menjadi sesuatu yang baru yang diperlukan bagi kehidupannya. Dalam perkembangannya, manusiapun terikat oleh hokum-hukum berfikir dalam upaya mengembangkan dan mewujudkan pemikirannya.

Jika pengertian ibadah ni dihubungkan dengan pengertian khalifah sebagaimana diuraikan sebelumnya dapat diperoleh pemahaman yaitu bahwa khalifah adalah pengganti yang memegang kepemimpinan an kekuasaan dari yang digantikan, ia menjadi pemegang kepemimpinan dan kekuasaan yang ada. Sebagai seorang pemimpin dan penguasa, manusia mempunyai wewenang untuk menentukan pilihan dan bebas untuk menggunakan akalnya, sedangkan 'abd adalah seorang yang telah

\footnotetext{
7 Musa Asy'ari, 1992, Manusia Pembentuk Kebudayaan dalam al-Qur'an, Yogyakarta, LSAF, halaman 43

${ }^{8}$ Musa Asy'ari, 1992, Manusia Pembentuk Kebudayaan dalam al-Qur'an, Yogyakarta, LSAF, halaman 43

${ }^{9}$ Hasan Langgulung, 1986, Manusia dan Pendidikan: Suatu Analisa Psikologis dan Pendidikan, Jakarta, Pustaka al-Husna, halaman 57
} 
kehilangan wewenang untuk menentukan pilihan dan kehilangan kebebasan untuk berbuat. Esensi seorang khalifah adalah kebebasan dan kreativitas, sedangkan seorang ' $a b d$ adalah ketaatan dan kepatuhan.

Dengan demikian kedudukan manusia di alam raya ini disamping sebagai khalifah yang memiliki kekuasaan untuk mengola alam dengan menggunakan segenap daya dan potensi yang dimilikinya, juga sekaligus sebagai ' $a b d$, yaitu seluruh usaha dan aktivitasnya itu harus dilaksanakan dalam rangka ibadah kepada Allah. Dengan pandangan yang terpadu ini, maka sebagai seorang khalifah tidak akan berbuat sesuatu yang mencerminkan kemunkaran atau bertentangan dengan kehendak Tuhan. Untuk dapat melaksanakan fungsi kekhalifahan dan ibadan dengan baik ini manusia perlu diberikan pendidikan, pengajaran, pengalaman, keterampilan, teknologi dan sarana pendukung lainnya. Ini menunjukkan bahwa konsep kekhalifahan dan ibdah dalam al-Qur'an erat kaitannya dengan pendidikan. Manusia yang dapat melaksankan fungsi-fungsi yang demikian itulah yang diharapkan muncul dari kegiatan usaha pendidikan.

\section{Kesempurnaan diri (al-kamal $)^{10}$}

Kesempurnaan (al-kamal) yang dimaksudkan HAMKA adalah kesempurnaan lahir dan batin ${ }^{11}$ Kesempurnaan lahir berkait dengan kesempurnaan karakter dan watak, yang secara operasional-empirik direalisasikan dengan terbiasanya seseorang melakukan perbuatanperbuatan terpuji seraya senantiasa menghindari perilaku-perilaku tercela dalam segala aspek kehidupannya. Kesempurnaan ini dimulai dengan menertibkan keutamaan-keutamaan jiwa (marah, syahwat atau nafsu dan akal) sehingga tidak saling berbeturan, namun hidup berkembang secara harmonis dalam diri manusia, agar seluruh aktivitasnya sesuai dengan fungsi masing-masing kekuatan jiwa tersebut serta tertata dengan baik. Sementara kesempurnaan batin merupakan kesempurnaan jiwa yang secara operasional empiric ditandai dengan kedekatan hamba dengan alKhaliq (Allah), sehingga digambarkan oleh HAMKA sebagai manusia yang telah mencapai tingkat akhir dari kemanusiaannya serta menyentuh pada awal alam malaikat. Inilah yang dikatakan sebagai tingkat paling tinggi bagi manusia, dimana pada tingkatan ini seluruh maujud bersatu menjadi satu kekuatan menuju keridlaan Allah. Dan dengan model

${ }^{10}$ HAMKA, 1983, Lembaga Budi, Jakarta, Pustaka Panjimas, halaman 2

\footnotetext{
${ }^{11}$ Terminologi kesempurnaan (al-kamal) lahir dan batin ini banyak dijumpai dalam berbagai karya HAMKA dalam rangka untuk menjelaskan bahwa manusia itu pada hakekatnya memerlukan kebutuhan lahir yang bersifat jasadi dan keperluan batin yang bersifat ruhani.
} 
kesempurnaan lahir batin inilah, manusia akan memperoleh al-sa'adah (kebahagiaan). ${ }^{12}$

\section{Keutamaan budi}

Yang dimaksud keutamaan budi oleh HAMKA ialah adanya kesadaran untuk melakukan perilaku terpuji secara konsisten, yang dimulai dengan pembiasaan-pembiasaan sebagai realisasi dari kesempurnaan lahir dan batin manusia ${ }^{13}$ HAMKA dalam hal in berpandangan bahwa kesempurnaan manusia sangat terkait dengan keutamaan budi ( $a l$-fadha'il), dimana keutamaan budi menuntut adanya keserasian tertentu dalam hubungan fungsional daya-aya yang dimiliki oleh manusia. Keutamaan budi (al-fadha'il) tersebut adalah: al-iffah sebagai keutamaan daya al-syahwat; al-syaja'ah sebagai keutamaan daya al-ghadhab; al-hikmat sebagai kekuatan akal; dan al-'adalah sebagai penyeimbang ketiga daya tersebut ${ }^{14}$. Lebih jelasnya sebagai berikut:

a. al-iffah sebagai keutamaan daya al-syahwat

Al- 'iffah merupakan kesanggupan untuk menahan dan menjaga diri dalam rangka menjaga kehormatan diri dari pengaruh dan kungkungan perilaku tercela (al-akhlak al-madzmumah). Al- iffah ini merupakan realisasi keseimbangan antara dua keburukan al-syahwat yaitu al-syarah (keserakahan) dan al-khumud (keadaan lemah keinginan atau acuh tak acuh) ${ }^{15}$

b. Al-syaja'ah sebagai keutamaan daya al-ghadhab

Al-syaja'ah merupakan sikap berani untuk melaksanakan aktivitas karena dilandasi oleh motivasi untuk menegakkan kebenaran dan takut pada kesalahan. Al-syaja'ah memiliki dua pinggir, pinggir sebelah atas terlalu panas atau terlalu berani yang bernama tahawwur (berani babi), dan pinggir ke sebelah bawah terlalu dingin itulah yang bernama jubun (pengecut) ${ }^{16}$. Penegakan sikap sikap syafa'ah merupakan realisasi dari upaya menegakkan kebenaran walaupun penuh rintangan.

c. Al-hikmat sebagai kekuatan akal

Al-hikmat merupakan keutamaan yang diberikan oleh Allah kepada manusia, agar dapat mengendalikan dorongan atau daya ghadabiyah dan daya syahwatiyah. HAMKA mengkonsepsikan Al-hikmat sebagai keseimbangan antara dua keburukan, yaitu sifat al-safah

\footnotetext{
12 HAMKA, Lembaga Hidup...Op Cit, halaman 192

${ }^{13}$ HAMKA, Filsafat Hidup...Op Cit, halaman 83

${ }^{14}$ Ibid, halaman 84

15 HAMKA, Filsafat Hidup.... Ibid, halaman 85; HAMKA, 1992, Akhlaqul Karimah, Jakarta, Pustaka Panjimas, halaman 5, HAMKA, 1990,Tasawuf Modern, Jakarta, Pustaka Panjimas, halaman 152

16 Ibid, halaman 153
} 
(tergesa-gesa dan tidak menggunakan pertimbangan) dan al-balah (kebodohan atau kekosongan pikiran) ${ }^{17}$ Jadi hikmah merupakan sikap dan sifat arif atau bijaksana dalam menghadapi suatu persoalan, baik persoalan yang berimplikasi kebaikan maupun persoalan yang berimplikasi pada keburukan.

d. Al-'adalah sebagai penyeimbang ketiga daya tersebut

$\mathrm{A} l$-'adalah merupakan sikap atau perilaku terpuji yang merupakan equilibrium (keseimbangan) dari dua segi yaitu segi penempatan masing-masing keutamaan (al-fadhilah) itu diantara dua keburukan dan dari segi penempatan akal sebagai control terhadap dorongan ghadabiyah dan syahwatiyah, dalam rangka mencapai kebenaran (alhikmat). Konsep HAMKA tentang Al-'adalah sebagai berikut:

1) Keadilan merupakan perangai mulia dari akal budi, daripada nafsu-nafsu marah dan daripada syahwat. Keadilan yang dimaksudkan disini ialah kepandaian mencampurkan "garm hidup", sehingga marah ada, hikmah ada, syahwat ada dan akal budipun terpakai ${ }^{18}$

2) Keadilan ialah timbangan kebenaran. Al-'adalah menimbulkan rasa kasih, terutama terhadap orang lemah dan orang teraniaya. Rasa adil dan rasa kasih ini haruslah dipupuk agar hilang sifat dzalim atau aniaya. Keadilan timbul dari hati sanubari, sehingga orang tidak mau menimpakan kepada oranglain suatu yang dia sendiri sanggup menerimanya ${ }^{19}$

Keempat keutamaan itulah yang akan membentuk budi pekerti atau moralitas terpuji dalam segala aspek kehidupan manusia. Dalam mewujudkan budi pekerti, peran akan sangat dominant dan urgen, bahkan dapat dikatakan bahwa dalam pandangan HAMKA daya akal-lah yang menjadi penentu bagi terwujudnya keutamaan budi atau pekerti, karena dari pelurusan daya akal maka akan menjadi lurus pula pentadbiran akal, kebaikan hati, kecerdasan pikiran dan kesucian diri. Pandangan ini membawa konsekwensi bahwa untuk mewujudkan tujuan pendidikan sebagaimana yang diidealkan, maka mendidik akal merupakan sesuatu yang niscaya. Dengan demikian keutamnaan budi dapat terwujud, maka akan mampu menghantarkan manusia memperoleh kebahagiaan sejati, sebagai tujuan akhir dari pendidikan pada manusia.

Menurut HAMKA, kebahagiaan itu tidaklah diukur dengan terpenuhinya kebutuhan manusia yang bersifat biologis-materialistik, hal

\footnotetext{
${ }^{17}$ Ibid, halaman 154

18 HAMKA, Tasawuf Modern...halaman 195

${ }^{19}$ HAMKA, Filsafat Hidup...halaman 88
} 
ini berdasar realitas-empirik bahwa dalam kehidupan sehari-hari terdapat individu yang memiliki kemampuan memenuhi kebutuhan biologismaterialistik, tetapi justru nampak lebih bahagia, karena itu kebahagiaan bukanlah berasal dari luar diri tappi dalam diri seseorang yaitu terpenuhinya kebutuhan mental spiritual ${ }^{20}$ Namun demikian, bukanlah kebahagiaan itu dimaksudkan oleh HAMKA hanya bersifat ukhrawi saja, dan meninggalkan aspek duniawi. Kebahagiaan yang dimaksudkan beliau adalah kebahagiaan yang seimbang antara aspek ukhrawi (mental spiritual) dan aspek duniawi (fisik-material), atau dengan bahasa yang biasa digunakan HAMKA adalah kebahagiaan lahir dan batin.

HAMKA membagi kebahagiaan menjadi 5 tingkatan yaitu:

1). Kebahagiaan yang hakiki atau kebahagiaan sejati yaitu kebahagiaan yang baqa, tidak ada fana padanya, penuh sukacita, tidak ada dukacita padanya. Seseorang tidak akan memperoleh kebahagiaan hakiki atau sejati apabila tidak melalui tingkatan kedua yaitu keutamaan akal budi

2). Keutamaan akal budi memiliki empat indicator yaitu: (a) sempurna akal (diperoleh dengan ilmu), (b) 'iffah (menjaga kehormatan diri); sempurna 'iffah ini ditempuh dengan jalan wara' artinya tiada peduli dengan bujukan manis dunia, (c) syaja'ah (berani karena benar dan takut karena salah); sempurna syaja'ah ini ditempuh dengan jalan jihad, (d) al'adl (keadilan); sempurna al-'adl ini ditempuh dengan jalan insyaf; kesempurnaan atau keutamaan akal budi ini tidak akan terwujud apabila melewati tingkatan ketiga yaitu keutamaan yang ada pada fisik atau tubuh manusia

3). Keutamaan yang ada pada fisik atau tubuh manusia ini diindikasikan terdapat empat indicator yaitu: (a) sehat jasmani, (b) kuat atau memiliki kemampuan beraktivitas, (c) elok atau memiliki kebersihan diri, serta (d) umur panjang. Keutamaan atau kesempurnaan yang ada pada fisik atau tubuh ini akan dapat terwujud apabila melewati tingkatan keempat yaitu keutamaan dari luar badan atau tubuh

4). Keutamaan dari luar badan atau tubuh ini juga diindikasikan terdapat empat indicator: (a) kaya akan harta bena, (b) kaya dengan famili, (c) terpandang dan terhormat, serta (d) memiliki kemuliaan keturunan. Keutamaan atau kesempurnaan dari luar badan atau tubuh ini akan terwujud bila melewati tingkatan kelima yaitu keutamaan yang datang lantaran taufiq dan hidayah Allah

${ }^{20}$ Ibid, halaman 148 
5). Keutamaan yang datang lantaran taufiq dan hidayah Allah mengandung empat kategori yaitu: (a) hidayat Allah (petunjuk Allah), (b) Irsyad Allah (ciptaan Allah), tasdid Allah (bantuan Allah) dan ta'jid (bantuan Allah) ${ }^{21}$

Konsep kebahagiaan hakiki sebagai tujuan akhir pendidikan sebagaimana yang dikonsepsikan oleh HAMKA adalah merupakan arah yang akan dicapai oleh seluruh aktivitas pendidikan. Yang dimaksud kebahagiaan hakiki adalah kebahagiaan sempurna atau kebahagiaan yang komprehensif-komulatif yaitu mencakup seluruh aspek kebutuhan hidup manusia, baik didunia maupun di akhirat. Karena itu pemikiran HAMKA tentang kebahagiaan hakiki sebagai tujuan akhir pendidikan- ini dapat disejajarkan dengan konsep al-sa'adah yang dikemukakan oleh Ibnu Miskawaih.

Konsep Ibnu Miskawaih tentang al-sa'adah walaupun secara umum diartikan sebagai happiness dalam Bahasa Inggris tapi sesungguhnya sulit dicari padan katanya, sebab al-sa'adah merupakan konsep yang komprehensif dan komulatif yang didalamnya terkandung unsure: happiness (kebahagiaan), prosperity (kemakmuran), success (keberhasilan), perfection (kesempurnaan), blessedness (kesenangan) dan beautide (kecantikan/kebagusan) ${ }^{22}$

Dari uraian diatas dapat disimpulkan bahwa tujuan akhir pendidikan dalam pandangan HAMKA adalah al-sa'adah atau kebahagiaan yang hakiki atau kebahagiaan yang paripurna. Walaupun untuk mencapai kebahagiaan yang hakiki atau kebahagiaan yang paripurna itu sangat sulit, namun sebagai suatu idealitas, maka harus tetap diupayakan. Untuk sampai pada tujuan akhir tersebut, terdapat tujuan-tujuan intermedier atau tujuan antara, yaitu: kesempurnaan diri dan keutamaan budi, dengan senantiasa berusaha mengarahkan pendidikan pada penempatan posisi manusia sebagai khlifah al-Allah $f i$ al-Ardl dan sebagai Abd.al-Allah. Dengan kata lain, aktivitas pendidikan dimulai dengan penanaman kesadaran bahwa manusia dilahirkan didunia ini pada hakekatnya memiliki tugas dan tanggung jawab sebagai khalifah Allah fi al-ardl, serta sebagai 'Abd.al-Allah.

Sebagai khalifah Allah fi al-ardl manusia dididik untuk cerdas, kreatif dan kritis dalam berbagai aspek kehidupan, sedang sebagai 'Abd.al-Allah manusia diberikan dasar-dasar kesadaran bahwa segala

\footnotetext{
${ }^{21}$ HAMKA, Tasawuf Modern...Op Cit, halaman 35

22 M.Abdul Haq Anshari, 1983, Miskawayh's Conception of Sa'adat, dalam Islamic Studies No. II/3, halaman 319
} 
aktivitas yang dilakukan semua merupakan realisasi dari sikap penghambaan diri kepada Allah. Dengan modal dasar kesadaran horizontal sebagai khalifah Allah fi al-ardl dan kesadaran vertical sebagai 'Abd.al-Allah, maka seseorang akan dengan mudah untuk diarahkan guna mencapai tujuan berikutnya, yaitu memperoleh keutamaan budi atau berbudi pekerti luhur dan kesempurnaan diri lahir dan batin, serta pada akhirnya akan menggapai kebahagiaan yang paripurna (al-sa'adah)

\section{Pemikiran Muhammad Iqbal tentang Tujuan Pendidikan}

Hasil pemikiran Iqbal mengenai pendidikan banyak tersirat dalam karyanya yang sebagian besar berbentuk puisi, sajak atau prosa. Sebagai filosof dan sekaligus seorang pujangga, Iqbal telah banyak meluangkan waktu dan perhatiannya terhadap persoalan-persoalan pendidikan. Dengan kata lain, seluruh pemikirannya secara kontekstual sesungguhnya telah mengisyaratkan perlunya dilakukan rekonstruksi di bidang pendidikan Islam. Melalui gubahan sajak-sajaknya, Iqbal melakukan kritik terhadap system pendidikan yang berlaku pada saat itu ${ }^{23}$

Pendidikan menurut Iqbal bukan proses mengajar atau belajar semata, karena kegiatan ini dianggap berlangsung secara sederhana atau mekanistis dan hanya berlangsung diantara empat dinding sekolah. Pendidikan dalam arti sempit ini tidak mampu mencakup pembinaan yang dapat membentuk, mengembangkan dan memodifikasi gagasan dan perbuatan perorangan atau kelompok. Iqbal berpendapat bahwa pendidikan harus dipandang sebagai suatu keseluruhan daya budaya yang mempengaruhi kehidupan perorangan maupuan kelompok manusia ${ }^{24}$ Dalam salah satu sajaknya ia menulis:

Aku tamat dari sekolah dan pesantren penuh duka,

\section{Disitu tak kutemukan kehidupan}

Tidak pula cinta

Tak kutemukan hikmah, dan tidak pula kebijaksanaan

Guru-guru sekolah adalah orang-orang yang tak punya nurani,

Mati rasa, mati selera

${ }^{23}$ Fazlur Rahman, 1995, Islam dan Modernitas: Tentang Transformasi Intelektual, alih bahasa Ahsin Mohammad, Bandung, Pustaka, halaman 66

${ }^{24}$ KG Sayidain, 191, Iqbal's Education Philosophy (Percikan Filsafat Iqbal mengenai Pendidikan), Alih Bahasa MI Soelaeman, Bandung, CV Diponegoro, halaman 20 


\section{Dan kyai-kyai adalah orang-orang yang tidak punya himmah,}

\section{Lemah cita, miskin pengalaman ${ }^{25}$}

Isi sajak tersebut merupakan kritikan Iqbal kepada system pendidikan Barat dan system pendidikan Islam tradisional. Iqbal memandang system pendidikan Barat lebih condong kepada materialisme, suatu kecenderungan yang nantinya merusak nilai-nilai spiritual manusia. Menurut Iqbal, pendidikan Barat hanya dapat mencetak manusia menjadi out put dengan memiliki intelektual tinggi, tetapi tanpa memiliki hati nurani yang berkualitas. Sistem pendidikan seperti itu pada akhirnya akan menyebabkan pertumbuhan dan perkembangan manusia tanpa keseimbangan antara aspek lahiriah dengan aspek batiniah ${ }^{26}$ Sementara itu pendidikan Islam tradisional dikritik Iqbal karena hanya memenjarakan otak dan jiwa manusia di dalam kurungan yang ketat. Dalam pandangan Iqbal, pendidikan tradisional tidak mampu mencetak manusia intelek yang dapat menyelesaikan berbagai persoalan keduniaan.

Dimata Iqbal, pendidikan adalah bagian tak terpisahkan dari peradaban manusia. Bahkan, pendidikan sekaligus menjadi substansi dari peradaban manusia ${ }^{27}$. Iqbal berpendapat bahwa pendidikan harus dipandang sebagai suatu keseluruhan daya budaya yang mempengaruhi kehidupan perorangan maupun kelompok masyarakat ${ }^{28}$ Oleh karenanya, lanjut Iqbal, pendidikan sesungguhnya bertujuan untuk membentuk "manusia" sejati/sempurna/insan kamil ${ }^{29}$.

Pandangan Iqbal tentang manusia sejati/sempurna/insan kamil tergambar dalam pendapatnya yang menyatakan bahwasanya untuk mengenal Tuhan hanya berpusat pada dirinya sendiri, mengenal diri sebaikbaiknya, dan untuk menyempurnakan diri bagi Iqbal harus menciptakan sifat-sifat ketuhanan di dalam diri agar dapat berperilaku seperti perilaku Tuhan $^{30}$. Cara penciptaan sifat-sifat Tuhan tidak merenung-renung sifat Tuhan kemudian masuk pada esensi yang mutlak seperti yang dilakukan al-

\footnotetext{
25 Dikutip dari Abul Hasan al -Nadwi, 1987, Pendidikan Islam yang Mandiri, alih bahasa Afifi Muhammad, Bandung, Dunia IImu, halaman 33

${ }^{26}$ Ibid, halaman 34

${ }^{27}$ Salahuddin al-Nadwi, 1995, Muhammad Iqbal wa Qadaya al-Tajdid, Studia Islamika, Vol.II.No.I, halaman 171

28 KG. Saiyidain, 1981, Iqball's Eductioon Philosophy (Percikan Filsafat Iqbal Mengenai Pendidikan), alih Bahasa MI Soelaeman, Bandung, CV Diponegoro, halaman 20

${ }^{29}$ Fazlur Rahman, Op Cit, halaman 67

${ }^{30}$ Danusuri, Op Cit, halaman 134
} 
Jilli $^{31}$, tetapi usaha yang gigih dengan menyerap sifat-sifat Tuhan ke dalam dirinya, hal ini sesuai dengan semboyan Iqbal "Takhallaqu bi Akhlaqillah" (berperangailah dengan perangai Tuhan). Jika perangai Tuhan telah terserap keseluruhannya berarti telah terjadi persatuan antara diri dan Tuhan (kata Iqbal bagi Tuhan laku, pikir dan penciptaan adalah identik). Karena manusia berpusat pada diri sendiri menyerap Tuhan bukan berarti manusia hanyut ke dalam Tuhan, tetapi Tuhanlah yang hanyut ke dalam manusia. Kalau manusia hanyut ke dalam Tuhan, kata Iqbal berarti hilang kepribadiannya.

Maka jelas bahwa menurut Muhammad Iqbal bentuk persatuan manusia dengan Tuhan tidak melalui proses kefanaan. Hal ini sesuai dengan apa yang beliau ilustrasikan yaitu : Ketika masih kecil, pernah sekali Nabi hilang di padang pasir. Halimah pengasuh beliau tidak dapat menahan rasa sedihnya, tapi sementara ia sedang mengembara di padang pasir untuk mencari anak yang hilang, ia mendengar suara yang mengatakan:

Janganlah gundah kau takkan kehilangan dia. Tidak, dunai seluruhnya akan hilang dalam dia. Individu sejati takkan hilang dalam dunia, malah dunialah yang akan hilang didalamnya,"32

Dari ilustrasi tersebut menunjukkan, bahwa manusia utama versi Iqbal mengesankan sebagai bayangan Tuhan. Untuk menciptakan kesempurnaan, manusia menyerap sifat-sifat Tuhan, jadi yang dimaksud insane bayangan Tuhan secara substansial manusia mempunyai wujud sendiri tetapi dihiasi dengan sifat-sifat Tuhan, sedangkan manusia menjadi satu dengan Tuhan bukanlah kesatuan hakikat (esensial), lebih-lebih dapat diketahui secara jelas bahwa konsep Tuhan, yaitu Tuhan diidentikkan sebagai realitas keseluruhan dan ego terakhir. Disebut ego karena seperti manusia menanggapi keluahan manusia. Dengan penuh kesadaran ia tidak mengelak dari corak antromorfis dalam ketuhanan, alasannya al Qur'an selalu menarik dan mengajak kepada yang terbatas dan konkrit ${ }^{33}$

Dari sini dapat diketahui bahwa posisi manusia sejati/sempurna/insan kamil versi Muhammad Iqbal ialah transendentalisme yaitu ada perbedaan tajam antara manusia dengan Tuhan - khalik dan makhluk ${ }^{34}$. Iqbal juga mengemukakan tentang ciri-ciri manusia sejati/sempurna/insan kamil yaitu:

${ }^{31}$ Muh.Iqbal, 1995, The Development of Metaphysucs in Persia: A Contribution to The History of Muslim Philosophy (Metafisikan Persia Suatu Sumbangan Untuk Sejarah Filsfat Islam). diterjemahkan Jobar Ayoeb, Bandung, Mizan, halaman 110

32 Muhammad Iqbal, 1996, The Recontruction on Religious Thought in Islam, (Membangun Kembali Alam Pikiran Islam) diterjemahkan Utsman Salibi, Jakarta, Bulan Bintang, halaman 5 33 Ibid, halaman 81

${ }^{34}$ Danusiri, Op Cit, halaman 136 
1) Manusia yang telah dilengkapi oleh Tuhan dengan beragai daya tangkap seperti serapan indera, rasio dan intuisi dalam kadar yang sangat tinggi oleh karena dapat merebut masa dan ruang, menguasai dunia. Dengan potensi itu manusia utama dapat menempuh kearah Tuhan mengenali diri dengan ketuhanan dan mengenali Tuhan cahaya diri

2) Manusia adalah teman kerja Tuhan di bumi, seperti yang dimuat dalam sajaknya:

Ku-mohonkan dari karunia-Mu sebagai kawan

Seorang murid dirahasia-rahasia alam semester

Seorang kawan penuh kegilaan dan khidmad

Seorang yang tak tahu penjelmaan hal-hal kosong

Agar dapat kupercayakan keluhnya kepada jiwanya

Dan melihat kembali wajahku di dalam kalbunya

Bayangnya hendak kubentuk dari tanah lempungku sendiri $^{35}$

Dari sajak diatas terlihat bahwa hubungan teman karib itu sangat dinamis. Dengan potensi masing-masing kedua belah pihak mencipta secara dialektik. Menurut Iqbal ciptaan Tuhan belum selesai, baru terwujud setengah jadi dan manusia yang bertugas mengolahnya menjadi barang konsumtif, seperti yang termaktub dalam sajak berikut ini:

Kau ciptakan malam dan aku yang membuat lampu

Kau menciptakan tanah liat dan aku yang membuat piala

Kau menciptakan sahara dan gunung-gunung dan belantara

Kau menciptakan kebun anggur, taman-taman padang tanaman ${ }^{36}$

Ringkasnya insan kamil sebagai teman kerja Tuhan kadang-kadang nampak terlibat dalam perundingan untuk mencipta suatu model tertentu.

\footnotetext{
${ }^{35}$ Muhammad Iqbal, 1987, Javid Namah, diterjemahkan Dr.Mohammad Sadikin, Jakarta, Pustaka Panti Mas, halaman 34

${ }^{36}$ Miss Luce-Claude Maitre, Op Cit, halaman 32
} 
3). Irada manusia utama adalah seiradah dengan Tuhan, seperti yang telah diungkapkan oleh Iqbal bahwa dalam kemauannya, iradah Tuhan hilang didalamnya ${ }^{37}$

4). Ilmu dan kekuasaan Tuhan menjadi kembar dengan ilmu dan kekuasaan manusia utama, senada dengan apa yang dikatakannya bahwa ilmuNya kembar dengan kodrat manusia utama

5). Insan kamil adalah orang yang tak terkendali oleh qada' dan qadar, melainkan mampu mengarahkannya kemana harus terjadi, "Padi dan sore si budak terikat dan kata qadha terucapkan pada qadar dan peristiwa zaman kedua telapak tangan si bebas melukis dan mengarahkannya" 38

Ciri-ciri manusia sejati/sempurna yang diutarakan Iqbal mirip dengan yang disampaikan oleh Ahmad Tafsir yang menyebutkan manusia sejati/sempurna menurut Islam yaitu: (1) Jasmani yang sehat serta kuat dan berketarampilan, (2) Cerdas serta pandai, (3) Rohani yang berkualitas tinggi ${ }^{39}$

Namun perlu diperhatikan bahwa manusia sejati/sempurna/insane kamil tidak akan terwujud hingga ego melampui proses yang mencakup tiga tahap, yaitu: (1) Ketaatan pada hukum, (2) Penguasaan diri sendiri yang merupakan bentuk tettinggi, kesadaran diri tentang pribadi, dan (3) Kekhalifahan Ilahi

"Naib atau manusia sejati/sempurna/insane kamil adalah khalifah Tuhan di muka bumi. Ia merupakan ego yang paling sempurna, puncak kehidupan, menal maupun keharmonisan. Kemampuan tertinggi bersaatu dalam dirinya menjadi pengetahuan tertinggi. Dalam dirinya pikiran dan perbuatan, naluri dan nalar menjadi satu. Ia adalah buah terakhir dari pohon kemanusiaan dibenarkan, sebab ia dating di saat terakhir. Ia adalah penguasa umat manusia yang sebenarnya; kerajaannya adalah kerajaan Tuhan di muka bumi",40

Dalam versi lain, Muhammad Iqbal, yang dikutip oleh Dawan Rahardjo ${ }^{41}$, memberikan criteria insan kamil dengan criteria insan yang beriman yang didalam dirinya terdapat kekuatan, wawasan, perbuatan, dan

\footnotetext{
${ }^{37}$ Danusiri, Op Cit, halaman 139

${ }^{38}$ Abdul Wahab 'Azzam, tt, Iqbal: Siratuh wa Falsafatuh wa Syi'ruh (Filsafat dan Puisi Iqbal), diterjemahkan oleh Ahmad Rofi' Usman, bandung, Pustaka Husna, halaman 175

${ }^{39}$ Ahmad Tafsur,1992, IImu Pendidikan dalam Perspektif Islam, Bandung, Remaja Rosdakarya, halaman 41

40 Muhamad Iqba, Javid...OpCit, halaman 35

41 Dawan Rahardjo (penyunting), 1989, Insan Kamil: Konsep Manusia menurut Islam, Jakarta, Temprint, halaman 26
} 
kebijaksanaan dan mempunyai sifat-sifat yang tercermin dalam pribadi Nabi saw, berupa akhlakul karimah. Tahapan untuik mencapai insal kamil itu diperoleh melalui ketaatan terhadap hokum-hukum Allah, penguasaan ini sebagai bentuk tertinggi kesadaran diri tentang pribadi dan kekhalifahan Ilahi.

Pendapat Muhammad Iqbal tentang tujuan pendidikan diatas hampir sama dengan pendapat beberapa cendekiawan muslim, karena mereka sepakat bahwa tujuan pendidikan ialah pembentukan pribadi muslim yang sejati/sempurna sebagai khalifat Allah di muka bumi, yang beriman dan beramal shaleh serta bahagia di dunia dan akhirat. Menurut al Ghazali, yang dikutip oleh Fathiyah Hasan Sulaiman ${ }^{42}$, tujuan umum pendidikan tercermin dalam dua segi yaitu (1) insan purna yang bertujuan mendekatkan diri kepada Allah swt, dan (2) insan purna yang bertujuan mendapatkan kebahagiaan hidup di dunia dan di akhirat. Kebahagiaan dunia akhirat dalam pandangan al-Ghazali adalah menempatkan kebahagiaan dalam proporsi yang sebenarnya. Kebahagiaan yang lebih memiliki nilai universal, abadi dan lebih hakiki itulah yang diprioritaskan

Ibnu Khaldun, yang dikutip oleh Muhammad Athiyah al Abrasyu merumuskan tujuan pendidikan dengan berpijak pada firman Allah dalam QS.al-Qashas: 77 yang berbunyi:

"Dan carilah pada apa yang telah dianugerahkan Allah kepadamu (kebahagiaan) negeri akhirat, dan janganlah kamu lupa bagian dari (kenikmatan) duniawi"

Berdasarkan Firman itu, Ibnu Khaldun merumuskan bahwa tujuan pendidikan Islam terbagi atas dua macam, yaitu (1) tujuan yang berorientasi ukhrawi, yaitu membentuk seorang hamba agar melakukan kewajiban kepada Allah, (2) Tujuan yang berorientasi duniawi, yaitu membentuk manusia mampu menghadapi segala bentuk kebutuhan dan tantangan kehidupan, agar hidupnya lebih layak dan bermanfaat bagi orang lain.

Muhammad Fadhil al-Jamali merumuskan tujuan pendidikan dengan empat macam, yaitu: (1) mengenalkan manusia akan peranannya diantara sesama titah makhluk dan tanggung jawabnya di dalam hidup ini, (2) mengenalkan manusia akan interaksi social dan tanggung jawabnya dalam tata hidup bermasyarakat, (3) mengenalkan manusia akan alam dan mengajak mereka untuk mengetahui hikmah diciptakannya serta memberi kemungkinan kepada mereka untuk mengambil manfaat darinya, (4)

\footnotetext{
42 Fathiyah Hasan Sulaiman, 1986, Sistem Pendidikan Versi al-Ghazali. terj. Fathur Rahman, Bandung, al-Ma'arif, halaman 24
} 
mengenalkan manusia akan pencipta alam (Allah) dan menyuruhnya beribadah kepadaNya ${ }^{43}$

Rumusan tujuan pendidikan yang dihasilkan dari seminar pendidikan Islam sedunia tahun 1980 di Islamabad adalah: Pendidikan seharusnya bertujuan mencapai pertumbuhan yang seimbang dalam kepribadian manusia secara totall melalui pelatihan spiritual, kecerdasan, rasio, perasaan, dan panca indra. Oleh karena itu, pendidikan seharusnya pelayanan bagi pertumbuhan manusia dalam segala aspeknya yang meliputi aspek spiritual, intelektual, imajinasi, fisik, ilmiah, linguistic, baik secara individu, maupun secara kolektif dan memotivasi semua aspek tersebut kearah kebaikan dan pencapaian kesempurnaan. Tujuan utama pendidikan bertumpu pada terealisasinya ketundukan kepada Allah swt baik dalam level individu, komunitas dan manusia secara luas. ${ }^{44}$

\section{Analisis Kritis Komparatif}

Dari pembahasan tentang pendidikan dalam konsep HAMKA DAN Muhammad Iqbal, maka dengan langkah analisis kritis komparatif diharapkan dapat diperoleh permasalahan kelebihan dan kekurangan masingmasing.

Muhammad Iqbal memandang bahwa tujuan akhir pendidikan adalah membina individualitas menjadi suatu pribadi yang mantap yang hanya dapat merealisasikan dirinya dalam gairah hidup yang meluap penuh aktivitas. Tujuan akhir pendidikan bukan sekedar kegiatan intelektual, melainkan tindakan yang memperdalam keseluruhannya, keberadaan ego dan mempertegas serta mempertajam kemauannya, disertai keyakinan yang kreatif bahwa dunia ini bukan sesuatu yang sekedar cukup dilihat, dikenal melalui berbagai konsep pandangan tertentu, melainkan sesuatu yang harus diciptakan dan dibuat kembali melalui kegiatan dan aktivitas yang berkesinambungan. Dengan lain perkataan bahwa tujuan pendidikan adalah terbentuknya insan kamil (manusia sempurna) yang muncul dari pencarian yang penuh semangat.

Ciri-ciri manusia sempurna versi Muhammad Iqbal adalah manusia yang telah dilengkapi oleh Tuhan dengan berbagai daya tangkap seperti serapan indera, rasio dan intuisi dalam kadar yang sangat tinggi oleh karena dapat merebut massa dan ruang, menguasai dunia. Dengan potensi ini manusia utama dapat menempuh kearah Tuhan mengenali diri dengan

\footnotetext{
${ }^{43}$ Muhammad Fadhil al-Jamali, 1986, Filsafat Pendidikan dalam al-Qur'an, terj. Judial Falasani, Surabaya, Bina IImu, halaman 3

${ }^{44}$ Arifin HM, 1991, Kapita Selekta Pendidikan Islam dan Umum, Jakarta, Bina Aksara, halaman 4
} 
ketuhanan dan mengenali Tuhan cahaya diri. Manusia adalah teman kerja Tuhan di bumi, maksudnya dengan potensi masing-masing kedua belah pihak mencipta secara dialektik, ciptaan Tuhan belum selesai, baru terwujud setengah jadi dan manuia yang bertugas mengolahnya menjadi barang konsumtif; iradah manusia utama adalah seiradah dengan Tuhan dan dalam kemauannya iradah Tuhan hilang di dalamnya; Ilmu dan kekuasaan Tuhan menjadi kembar dengan ilmu dan kekuasaan manusia utama; insan kamil bukanlah orang yang terkendali oleh qada' dan qadar, melainkan mampu mengarahkannya kemana harus terjadi ${ }^{45}$

Manusia sempurna (insan kamil) akan terwujud melalui proses yang mencakup tiga tahap, yakni ketaatan pada hukum, penguasaan diri sendiri yang merupakan bentuk tertinggi kesadaran diri tentang pribadi, dan kekhalifahan Ilahi. Disamping itu, Muhammad Iqbal menyatakan bahwa untuk mengenal Tuhan hanya berpusat pada dirinya sendiri, mengenal diri sebaik-baiknya, dan untuk menyempurnakan harus menciptakan sifat-sifat ketuhanannya di dalam diri agar dapat berperilaku seperti perilaku Tuhan ${ }^{46}$ Cara penciptaan sifat-sifat Tuhan tidak merenung-renung sifat Tuhan kemudian masuk pada esensi nan mutlak seperti yang dilakukan al-Jilli ${ }^{47}$, tetapi usaha yang gigih dengan menyerap sifat-sifat Tuhan ke dalam dirinya, yakni Takhallaqu bi Akhlaqillah (berperangailah dengan perangai Tuhan). Jika perangai Tuhan telah terserap keseluruhannya berarti telah terjadi persatuan antara diri dan Tuhan (kata Iqbal bagi Tuhan, laku, pikir dan penciptaan adalah identik). Posisi insan kamil versi Iqbal adalah transendental, yakni ada perbedaan tajam antara manusia dengan Tuhankhalik dan makhluk.

HAMKA sependapat dengan Muhammad Iqbal tentang tujuan akhir pendidikan. Dengan redaksi yang berbeda, beliau mengatakan bahwa tujuan akhir dari pendidikan ialah kesempurnaan diri (al-kamal) dan keutamaan budi sehingga dapat memperoleh kebahagiaan sejati.

Kesempurnaan (al-kamal) yang dimaksudkan HAMKA adalah kesempurnaan lahir dan batin $^{48}$ Kesempurnaan lahir berkait dengan kesempurnaan karakter dan watak, yang secara operasional-empirik

\footnotetext{
${ }^{45}$ Abdul Wahab 'Azzam, tt, Iqbal: Siratuh wa Falsafatu wa Syi'ruh (Fislafat dan Puisi Iqbal), diterjemahkan oleh Ahmad Rofi' Usman, Bandung, Pustaka, halaman 175

${ }^{46}$ Danusiri, 1996, Epistemologi dalam Tasawuf Iqbal, Yogyakarta, Pustaka Pelajar, halaman 134

47 Muh.lqbal, 1995, The Development of Metaphysie in Peria: A Contribution to The History of Muslim Philosophy (Meetafisika Persia suatu sumbangan untuk sejarah Filsafat Islam), diterjemahkan Joebar Ayoeb, Bandung, Mizan, halaman 110

${ }^{48}$ Terminologi kesempurnaan (al-kamal) lahir dan batin ini banyak dijumpai dalam berbagai karya HAMKA dalam rangka untuk menjelaskan bahwa manusia itu pada hakekatnya memerlukan kebutuhan lahir yang bersifat jasadi dan keperluan batin yang bersifat ruhani.
} 
direalisasikan dengan terbiasanya seseorang melakukan perbuatan-perbuatan terpuji seraya senantiasa menghindari perilaku-perilaku tercela dalam segala aspek kehidupannya. Kesempurnaan ini dimulai dengan menertibkan keutamaan-keutamaan jiwa (marah, syahwat atau nafsu dan akal) sehingga tidak saling berbenturan, namun hidup berkembang secara harmonis dalam diri manusia, agar seluruh aktivitasnya sesuai dengan fungsi masing-masing kekuatan jiwa tersebut serta tertata dengan baik. Sementara kesempurnaan batin merupakan kesempurnaan jiwa yang secara operasional empiric ditandai dengan kedekatan hamba dengan al-Khaliq (Allah), sehingga digambarkan oleh HAMKA sebagai manusia yang telah mencapai tingkat akhir dari kemanusiaannya serta menyentuh pada awal alam malaikat. Inilah yang dikatakan sebagai tingkat paling tinggi bagi manusia, dimana pada tingkatan ini seluruh maujud bersatu menjadi satu kekuatan menuju keridlaan Allah. Dan dengan model kesempurnaan lahir batin inilah, manusia akan memperoleh al-sa'adah (kebahagiaan).

Yang dimaksud keutamaan budi oleh HAMKA ialah adanya kesadaran untuk melakukan perilaku terpuji secara konsisten, yang dimulai dengan pembiasaan-pembiasaan sebagai realisasi dari kesempurnaan lahir dan batin manusia ${ }^{49}$ HAMKA dalam hal in berpandangan bahwa kesempurnaan manusia sangat terkait dengan keutamaan budi (al-fadha'il), dimana keutamaan budi menuntut adanya keserasian tertentu dalam hubungan fungsional daya-daya yang dimiliki oleh manusia. Keutamaan budi (al-fadha'il) tersebut adalah: al-iffah sebagai keutamaan daya alsyahwat; al-syaja'ah sebagai keutamaan daya al-ghadhab; al-hikmat sebagai kekuatan akal; dan al- 'adalah sebagai penyeimbang ketiga daya tersebut ${ }^{50}$.

Kebahagiaan itu tidaklah diukur dengan terpenuhinya kebutuhan manusia yang bersifat biologis-materialistis, hal ini berdasar realita empiric bahwa dalam kehidupan sehari-hari terdapat individu yang memiliki kemampuan memenuhi kebutuhan biologis-materialistik, tetapi justru nampak lebih bahagia, karena itu kebahagiaan bukanlah berasal dari luar diri tapi dalam diri seseorang yaitu terpenuhinya kebutuhan mental spiritual ${ }^{51}$. Namun demikian, bukanlah kebahagiaan itu dimaksudkan HAMKA hanya bersifat ukhrawi saja, dan meninggalkan aspek duniawi. Kebahagiaan yang dimakudkan beliau adalah kebahagiaan yang seimbang antara aspek ukhrawi (mental spiritual) dan aspek duniawi (fisik-material), atau dengan bahasa yang biasa digunakan HAMKA adalah kebahagiaan lahir dan batin.

\footnotetext{
${ }^{49}$ HAMKA, Filsafat Hidup...Op Cit, halaman 83

${ }^{50} \mathrm{Ibid}$, halaman 84

${ }^{51}$ HAMKA, Filafat Hidup...halaman 88
} 
Pendapat Muhammad Iqbal dan HAMKA tentang tujuan akhir pendidikan intinya sama yaitu membentuk manusia sempurna yang senantiasa memiliki kebahagiaan yang sempurna tidak hanya di dunia tapi juga di akhirat. Muhammad Iqbal tidak setuju dengan teori para sufi seperti pemikiran al-Jili. Menurut dia, hal ini membunuh individualitas dan melemahkan jiwa. Iqbal memang memandang dan mengakui Nabi Muhammad SAW sebagai insan kamil, tetapi tanpa penafsiran secara mistik. Insan kamil versi Iqbal tidak lain adalah sang mukmin, yang dalam dirinya terdapat kekuatan, wawasan, perbuatan, dan kebijaksanaan. Sifat-sifat luhur ini dalam wujudnya yang tertinggi tergambar dalam akhlak Nabi SAW. Insan kamil bagi Iqbal adalah sang mukmin yang merupakan makhluk moralis, yang dianugerahi kemampuan rohani dan agamawi. Untuk menumbuhkan kekuatan dalam dirinya, sang mukmin senantiasa meresapi dan menghayati akhlak Ilahi. Sang mukmin menjadi tuan terhadap nasibnya sendiri dan secara tahap demi tahap mencapai kesempurnaan. Iqbal melihat, insan kamil dicapai melalui beberapa proses. Pertama, ketaatan pada hukum; kedua penguasaan diri sebagai bentuk tertinggi kesadaran diri tentang pribadi; dan ketiga kekhalifahan Ilahi.

Selanjutnya Iqbal mengemukakan ciri-ciri manusia sempurna/insan kamil, yaitu:

a. Manusia yang telah dilengkapi oleh Tuhan dengan berbagai daya tangkap seperti serapan indera, rasio dan intuisi dalam kadar yang sangat tinggi oleh karena dapat merebut masa dan ruang, menguasai dunia. Dengan potensi itu manusia utama dapat menempuh kearah Tuhan mengenali diri dengan ketuhanan dan mengenali Tuhan cahaya diri

b. Manusia adalah teman kerja Tuhan di bumi, seperti yang dimuat dalam sajaknya:

Ku-mohonkan dari karunia-Mu sebagai kawan

Seorang murid dirahasia-rahasia alam semester

Seorang kawan penuh kegilaan dan khidmad

Seorang yang tak tahu penjelmaan hal-hal kosong

Agar dapat kupercayakan keluhnya kepada jiwanya

Dan melihat kembali wajahku di dalam kalbunya

Bayangnya hendak kubentuk dari tanah lempungku sendiri ${ }^{52}$

\footnotetext{
52 Muhammad Iqbal, 1987, Javid Namah, diterjemahkan Dr.Mohammad Sadikin, Jakarta, Pustaka Panti Mas, halaman 34
} 
Dari sajak diatas terlihat bahwa hubungan teman karib itu sangat dinamis. Dengan potensi masing-masing kedua belah pihak mencipta secara dialektik. Menurut Iqbal ciptaan Tuhan belum selesai, baru terwujud setengah jadi dan manusia yang bertugas mengolahnya menjadi barang konsumtif, seperti yang termaktub dalam sajak berikut ini:

Kau ciptakan malam dan aku yang membuat lampu

Kau menciptakan tanah liat dan aku yang membuat piala

Kau menciptakan sahara dan gunung-gunung dan belantara

Kau menciptakan kebun anggur, taman-taman padang tanaman ${ }^{53}$

Ringkasnya insan kamil sebagai teman kerja Tuhan kadang-kadang nampak terlibat dalam perundingan untuk mencipta suatu model tertentu.

c. Irada manusia utama adalah seiradah dengan Tuhan, seperti yang telah diungkapkan oleh Iqbal bahwa dalam kemauannya, iradah Tuhan hilang didalamnya ${ }^{54}$

d. Ilmu dan kekuasaan Tuhan menjadi kembar dengan ilmu dan kekuasaan manusia utama, senada dengan apa yang dikatakannya bahwa ilmuNya kembar dengan kodrat manusia utama

e. Insan kamil adalah orang yang tak terkendali oleh qada' dan qadar, melainkan mampu mengarahkannya kemana harus terjadi, "Padi dan sore si budak terikat dan kata qadha terucapkan pada qadar dan peristiwa zaman kedua telapak tangan si bebas melukis dan mengarahkannya",55

Ciri-ciri manusia sejati/sempurna yang diutarakan Iqbal Nampak identik dengan pendapat beberapa cendekiawan muslim, karena mereka sepakat bahwa tujuan pendidikan adalah pembentuk pribadi muslim yang sempurna sebagai khalifah Allah di muka bumi yang beriman dan beramal shaleh serta bahagia didunia dan akhirat. Menurut Ahmad Tafsir yang menyebutkan manusia sejati/sempurna menurut Islam yaitu: (1) Jasmani yang sehat serta kuat dan berketarampilan, (2) Cerdas serta pandai, (3) Rohani yang berkualitas tinggi ${ }^{56}$

\footnotetext{
${ }^{53}$ Miss Luce-Claude Maitre, Op Cit, halaman 32

${ }^{54}$ Danusiri, Op Cit, halaman 139

${ }^{55}$ Abdul Wahab 'Azzam, tt, Iqbal: Siratuh wa Falsafatuh wa Syi'ruh (Filsafat dan Puisi lqbal), diterjemahkan oleh Ahmad Rofi' Usman, bandung, Pustaka Husna, halaman 175

${ }^{56}$ Ahmad Tafsur,1992, Ilmu Pendidikan dalam Perspektif Islam, Bandung, Remaja Rosdakarya, halaman 41
} 
Namun perlu diperhatikan bahwa manusia sempurna/insan kamil tidak akan terwujud hingga ego melampui proses yang mencakup tiga tahap, yaitu: (1) Ketaatan pada hokum, (2) Penguasaan diri sendiri yang merupakan bentuk tertinggi, kesadaran diri tentang pribadi, dan (3) Kekhalifahan Ilahi

"Nasib atau manusia sejati/sempurna/insane kamil adalah khalifah Tuhan di muka bumi. Ia merupakan ego yang paling sempurna, puncak kehidupan, menal maupun keharmonisan. Kemampuan tertinggi bersaatu dalam dirinya menjadi pengetahuan tertinggi. Dalam dirinya pikiran dan perbuatan, naluri dan nalar menjadi satu. Ia adalah buah terakhir dari pohon kemanusiaan dibenarkan, sebab ia datAng di saat terakhir. Ia adalah penguasa umat manusia yang sebenarnya; kerajaannya adalah kerajaan Tuhan di muka bumi ${ }^{\text {,57 }}$

Dalam versi lain, Muhammad Iqbal, yang dikutip oleh Dawan Rahardjo ${ }^{58}$, memberikan criteria insan kamil dengan criteria insan yang beriman yang didalam dirinya terdapat kekuatan, wawasan, perbuatan, dan kebijaksanaan dan mempunyai sifat-sifat yang tercermin dalam pribadi Nabi saw, berupa akhlakul karimah. Tahapan untuik mencapai insal kamil itu diperoleh melalui ketaatan terhadap hokum-hukum Allah, penguasaan ini sebagai bentuk tertinggi kesadaran diri tentang pribadi dan kekhalifahan Ilahi.

Pendapat Muhammad Iqbal dan HAMKA tentang tujuan pendidikan diatas hampir sama dengan pendapat beberapa cendekiawan muslim, karena mereka sepakat bahwa tujuan pendidikan ialah pembentukan pribadi muslim yang sejati/sempurna sebagai khalifat Allah di muka bumi, yang beriman dan beramal shaleh serta bahagia di dunia dan akhirat. Menurut al Ghazali, yang dikutip oleh Fathiyah Hasan Sulaiman ${ }^{59}$, tujuan umum pendidikan tercermin dalam dua segi yaitu (1) insan purna yang bertujuan mendekatkan diri kepada Allah swt, dan (2) insan purna yang bertujuan mendapatkan kebahagiaan hidup di dunia dan di akhirat. Kebahagiaan dunia akhirat dalam pandangan al-Ghazali adalah menempatkan kebahagiaan dalam proporsi yang sebenarnya. Kebahagiaan yang lebih memiliki nilai universal, abadi dan lebih hakiki itulah yang diprioritaskan. HAMKA menambahkan bahwa untuk sampai pada tujuan yang diakuinya sangat sulit itu ada tujuan-tujuan intermedier atau tujuan antara yaitu kesempurnaan diri dan keutamaan budi, dengan senantiasa berusaha mengarahkan pendidikan pada penempatan

${ }^{57}$ Muhamad Iqba, Javid...OpCit, halaman 35

58 Dawan Rahardjo (penyunting), 1989, Insan Kamil: Konsep Manusia menurut Islam, Jakarta, Temprint, halaman 26

59 Fathiyah Hasan Sulaiman, 1986, Sistem Pendidikan Versi al-Ghazali. terj. Fathur Rahman, Bandung, al-Ma'arif, halaman 24 
posisi manusia sebagai khalifah al Allah fi al-Ardll dan sebagai Abd. AlAllah. Lebih lanjut HAMKA mengatakan bahwa aktivitas pendidikan dimulai dengan penanaman kesadaran bahwa manusia dilahirkan di dunia ini pada hakekatnya memiliki tugas dan tanggung jawab sebagai khalifah al Allah fi al-Ardll serta sebagai Abd. Al-Allah.

Sebagai Abd. Al- Allah manusia dididik untuk cerdas, kreatif dan kritis dalam berbagai aspek kehidupan, sedang sebagai Abd. Al- Allah manusia diberikan dasar-dasar kesadaran bahwa segala aktivitas yang dilakukan semua merupakan realisasi dari sikap penghambaan diri kepada Allah.

1. Persamaan Pemikiran HAMKA dan Muhammad Iqbal tentang Tujuan Pendidikan

Baik HAMKA maupun Muhammad Iqbal berpendapat bahwa tujuan pendidikan adalah membentuk manusia sempurna yang senantiasa memiliki kebahagiaan yang sempurna tidak hanya di dunia tapi juga di akhirat.

2. Perbedaan Pemikiran HAMKA dan Muhammad Iqbal tentang Tujuan Pendidikan

a. Tujuan Pendidikan dalam Pandangan HAMKA

1) Tujuan pendidikan; tujuan akhir dari pendidikan ialah kesempurnaan diri (al-kamal) dan keutamaan budi sehingga dapat memperoleh kebahagiaan sejati.

2) Sifat yang harus dimiliki peserta didik agar berhasil dalam mencapai tujuan yaitu (a) memiliki sikap rendah hati, (b) memiliki etika kepada orang tua, guru, teman dan al-Khaliq, (c) dan menunjukkan akhlaq al karimah

b. Tujuan Pendidikan dalam Pandangan Muhammad Iqbal

1) Tujuan pendidikan; Manusia sempurna (insan kamil) akan terwujud melalui proses yang mencakup tiga tahap, yakni ketaatan pada hukum, penguasaan diri sendiri yang merupakan bentuk tertinggi kesadaran diri tentang pribadi, dan kekhalifahan Ilahi

2) Sifat yang harus dimiliki peserta didik agar berhasil dalam mencapai tujuan yaitu (1) motivasi tinggi dan bekerja keras, (2) mempunyai rasa percaya diri yang kuat dan tidak bergantung pada orang lain, (3) mempunyai rasa saling mencintai terhadap 
sesama, (4) selalu taat pada peraturan yang ada, dan (5) mempunyai sifat berani dan menghindari rasa takut

\section{E. Penutup}

Tujuan pendidikan dalam pandangan HAMKA ialah tercapainya kebahagiaan yang hakiki atau kebahagiaan yang paripurna; dan agar berhasil dalam mencapai tujuan itu sifat yang harus dimiliki peserta didik yaitu (a) memiliki sikap rendah hati, (b) memiliki etika kepada orang tua, guru, teman dan al-Khaliq, (c) dan menunjukkan akhlaq al karimah

Tujuan pendidikan dalam pandangan Muhammad Iqbal adalah membentuk "manusia" sejati/sempurna/insan kamil; dan agar berhasil dalam mencapai tujuan itu sifat yang harus dimiliki peserta didik adalah: (1) motivasi tinggi dan bekerja keras, (2) mempunyai rasa percaya diri yang kuat dan tidak bergantung pada orang lain, (3) mempunyai rasa saling mencintai terhadap sesama, (4) selalu taat pada peraturan yang ada, dan (5) mempunyai sifat berani dan menghindari rasa takut

Tujuan pendidikan dalam pemikiran HAMKA dan Muhammad Iqbal adalah intinya sama yaitu membentuk manusia sempurna yang senantiasa memiliki kebahagiaan yang sempurna tidak hanya di dunia tapi juga di akhirat.

Sedangkan perbedaannya adalah dalam pandangan HAMKA tujuan akhir dari pendidikan ialah kesempurnaan diri dan keutamaan budi sehingga dapat memperoleh kebahagiaan sejati; sedangkan menurut Muhammad Iqbal manusia sempurna akan terwujud melalui proses yang mencakup ketaatan pada hokum, penguasaan diri sendiri yang merupakan bentuk tertinggi kesadaran diri tentang pribadi dan kekhalifahan Ilahi. 


\section{DAFTAR PUSTAKA}

Abdul Mujib, 2006, Ilmu Pendidikan Islam, Jakarta, Kencana Prenada Media

Abul Hasan al -Nadwi, 1987, Pendidikan Islam yang Mandiri, alih bahasa Afifi Muhammad, Bandung, Dunia Ilmu

Abdul Wahab 'Azzam, tt, Iqbal: Siratuh wa Falsafatuh wa Syi'ruh (Filsafat dan Puisi Iqbal), diterjemahkan oleh Ahmad Rofi' Usman, bandung, Pustaka Husna

Agus Hakim, Kulliyatul Mubalighien Muhammadiyah dan Buya HAMKA, 1978, Kenang-kenangan 70 Tahun Buya HAMKA, Jakarta, Yayasan Nurul Islam

Ahmad D Marimba, 1989, Pengantar Filsafat Pendidikan, Bandung, alMa'arif

Ahmad TafsIr,1992, Ilmu Pendidikan dalam Perspektif Islam, Bandung, Remaja Rosdakarya

Arifin HM, 1991, Kapita Selekta Pendidikan Islam dan Umum, Jakarta, Bina Aksara

Danusiri, 1996, Epistemologi dalam Tasawuf Iqbal, Yogyakarta, Pustaka Pelajar

Dawan Rahardjo (penyunting), 1989, Insan Kamil: Konsep Manusia menurut Islam, Jakarta, Temprint

Fathiyah Hasan Sulaiman, 1986, Sistem Pendidikan Versi al-Ghazali. terj. Fathur Rahman, Bandung, al-Ma'arif,

Fazlur Rahman, 1995, Islam dan Modernitas: Tentang Transformasi Intelektual, alih bahasa Ahsin Mohammad, Bandung, Pustaka

HAMKA, 1983, Lembaga Budi, Jakarta, Pustaka Panjimas,

HAMKA, 1990, Tasawuf Modern, Jakarta, Pustaka Panjimas

HAMKA, 1992, Akhlaqul Karimah, Jakarta, Pustaka Panjimas

HAMKA, 1997, Lembaga Hidup, Jakarta, Pustaka Panjimas 
Hasan Langgulung, 1986, Manusia dan Pendidikan: Suatu Analisa Psikologis dan Pendidikan, Jakarta, Pustaka al-Husna

KG. Saiyidain, 1981, Iqball's Eductioon Philosophy (Percikan Filsafat Iqbal Mengenai Pendidikan), alih Bahasa MI Soelaeman, Bandung, CV Diponegoro

M.Abdul Haq Anshari, 1983, Miskawayh's Conception of Sa'adat, dalam Islamic Studies No. II/3

Musa Asy'ari, 1992, Manusia Pembentuk Kebudayaan dalam al-Qur'an, Yogyakarta, LSAF

Muh.Iqbal, 1995, The Development of Metaphysucs in Persia: A Contribution to The History of Muslim Philosophy (Metafisikan Persia Suatu Sumbangan Untuk Sejarah Filsfat Islam). Diterjemahkan Jobar Ayoeb, Bandung, Mizan

Muhammad Fadhil al-Jamali, 1986, Filsafat Pendidikan dalam al-Qur'an, terj. Judial Falasani, Surabaya, Bina Ilmu

Muhammad Iqbal, 1987, Javid Namah, diterjemahkan Dr. Mohammad Sadikin, Jakarta, Pustaka Panti Mas

Salahuddin al-Nadwi, 1995, Muhammad Iqbal wa Qadaya al-Tajdid, Studia Islamika, Vol. II. No. I 